\title{
Extension-Based versus Creation-Based Strategies in Tangiblizing e-Brands: A Preliminary Study
}

\author{
Chi-Shan Chen \\ Department of International Trade, Shih-Chien University, Kaohsiung campus \\ 200, University Road, Neiman, Kaohsiung, 845, Taiwan \\ Tel: 886-7667-8888Ｅ-mail: cjshan@mail.kh.usc.edu.tw
}

Frank Pan (Corresponding author)

Dept. of Hospitality Management, Tajen University

20, Wei-Hsin Rd., Yenpu, Pingtung, 900, Taiwan

Tel: 886-8762-4002Ｅ-mail: profpan900@gmail.com

Ching-Huei Liu

Graduate Institute of Leisure Management, Tajen University

Bachelor Program of Tourism Culture Development, Kun Shan University

No.195, Kunda Rd., YongKang Dist., Tainan City, 710-03, Taiwan

Tel: 886-6205-0230_E-mail: liuch@mail.ksu.edu.tw

Received: May 9, 2014 Accepted: June 3, 2014 Published: June 27, 2014

doi:10.5296/bms.v5i1.5607 URL: http://dx.doi.org/10.5296/bms.v5i1.5607

\begin{abstract}
Purpose of this research was to explore how a brand-equity could be leveraged in establishing the customer equity in the online environment. Existing research has not yet explored how the tangibilization affects various branding and e-branding approaches. We seek to identify the possible effects of tangibilization in firms' attempts in gaining customer equity through
\end{abstract}


efforts of branding online. Findings of this study include highlighting both types of e-branding approaches, extension-based (e-EBA) and creation-based (e-CBA); have distinctive power in gaining respective equities in the virtual world in which the brand extension may have superior position by leveraging brand equity offline whereas new brand is free to fully utilized Internet technology. Both e-EBA and e-CBA shall seek to tangibilize their services to well categorized customers, since service tangibilization would significantly mediate the relationship between brands and customer equity. This paper would bring managers several implications. The key to the success in online expansion is the brand used online and the associated tangibilize activities in building customer relationship and gaining customer equity.

Keywords: Brand extension, e-Branding, Tangibilization, Customer equity 


\section{Introduction}

Based on the Internet as a reliable tool in information exchange (e.g. Morris et al., 2003), the on-line business or its equivalent is increasing importance not only because of the attractive volumes of on-line spending, but also the huge cost-effective benefits. In addition, the Internet brought customers multi-sensory experiences that were impossible with traditional approaches. This helped improving the quality and quantity of exchanges with current and prospective customers, and efficiently aligning marketing functions (Cespedes, 1996). However, the Internet also brought customers a newer and faster approach to access product knowledge among competitors, and accordingly to build brand attitude and purchase intention ( $\mathrm{Li}$ et al., 2002) in a different approach. Exchange on an Internet-based environment is, nevertheless, a challenge to both the suppliers and the customers.

\subsection{Business Operation Online}

Traditionally, marketers adopt various marketing activities in a mode of one-to-many communications to reach possible customers and prospects (Dussart, 2001; de Chernatony, 2001). Growing businesses take advantages of innovative Internet technology to integrate diverse communications with the customers in a timely and interactive manner (Dussart, 2001; Hoffman \& Novak, 1996). This not only expanded the marketing access capability but also making mass-customized service possible. Operating with an ideal integrated marketing communication (IMC) would be economically feasible.

Well-designed online operation, the marketers may collect and analyze customer's data in a form of continuous and speedy ways with lower costs, with which to erect a customer relationship (Walsh \& Godfrey, 2000). In this erection process, the brand acted as an identification of a service supplier to convince customers (Aaker, 1996), to serve customers, and to build a brand equity in customers' mind. Contrast to other predictions (Indrajit, 2001) that predicted the brand effects will disappear in a virtual context. The role of a brand played proved to be a signal for reliability and trustworthiness in this highly intangible business world (Bergstrom, 2000; Smith \& Brynjolfsson, 2001; Page \& Lepkowska-White, 2002). Moreover, an e-brand may convince customers that the technology-based online services promised a more customer-oriented service. This will in turn result in more customers' perceived value; eventually advance corporate brand equity by reciprocal effects (Balachander \& Ghose, 2003). This means a successful e-branding not only help fostering the relationship with customers with customized communication on an individual basis (Walsh \& Godfrey, 2000), but also creating a new marketplace that was not found and served through traditional channel.

Perceived intangibility is perhaps the major threat that was detrimental to service quality and customer acceptance (Parasuraman, et al., 1988; Santos, 2002) because customers may expose to a higher level of risk (Flipo, 1988), anxiety (Rushton \& Carson, 1989), uncertainty (Trivedi \& Morgan, 2003). As a result, customers were forced to sacrifice some processes of evaluating and assessing alternatives with competing services (Rushton \& Carson, 1989; 
McDougall \& Snetsinger, 1990). Consequently, wary emerged over the services in question (Rushton \& Carson, 1989). The brand-extension approach leveraged the brand equity may signal the current customers with a quality sign, yet the new brand approach may be more flexible in embracing internet technology because of no previous commitments or ties with current customers. In other words, the virtual markets can be a 'blue ocean' for all players and their brands because the customers' perception of intangibility.

Creating and maintaining a quality relationship that stemmed from higher level of customer satisfaction is essential for business performance (Oliver, 1997; Zeithaml \& Bitner, 2000). Given the fact that costs in acquiring new customers are five times higher retaining current customers (Keller, 2002), increases of the customer retention rates dramatically contribute to profit (Reichheld, 1996). As far as the customer-oriented perspective in marketing, main expectation from well managing the preferable customer relationship (Blattberg \& Deighton, 1996 ) is to create a reliable source for later generation of highest customer life value (Bolton \& Drew 1991; Reinartz \& Kumar, 2000; Gupta et al., 2004). A customer lifetime value is driven by customer equity (Rust, Lemon, \& Zeithaml, 2004) that includes three elements of customer equity, brand equity, value equity, and relationship equity (Rust et al., 2004). Value equity is the objectively considered quality, price, and convenience of the offering based on perceptions of its benefits relative to its cost. Although two distinctive perspectives regarding brand equity exist, one as financial asset of a company and another as the acceptance of targeted customers (Smith \& Parr, 2000; Schultz, 2003), brand equity is the customer's subjective and intangible assessment of the worth of brand offering that exceeds perceived value. Brands will not be valued and hardly make brand equity prized unless significant customer acceptance (Bottomley \& Holden, 2001). Relationship equity is a factor in switching cost, like as the customer's reluctance to go elsewhere because of learning curves, user-community benefits, or other considerations such as simple as friendships with salespeople (Kotler, 1996; Rust et al., 2004).

Both brand-extension and new-brand would be eligible to improve customer equity through the assistance of internet technology as long as the brand's offering could be specifically tangible in response to target customers' needs and wants. We propose that tangibilization would be the key to offset the negative impacts of online features. Tangibilization refers to a set of activities marketers adopted to create significant 'tangibility' in customers' mind. Figure 1 shows our conceptual framework that explains the relationship between e-branding, tangibilization, and customer equity as well. 


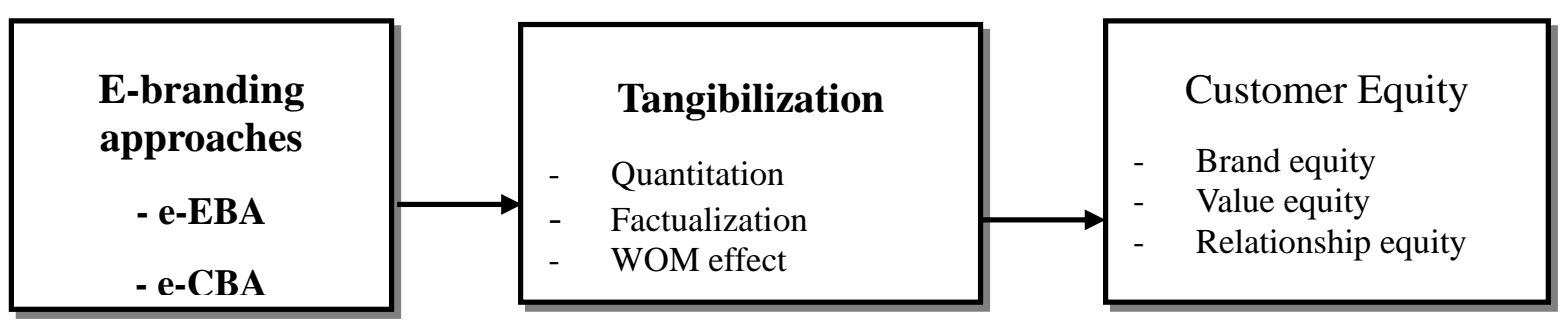

Figure 1. E-branding, tangibilization, and customer equity

\section{Online Branding Strategies and the Effects of Service Tangibilization}

\subsection{E-Branding and Customer Relationship}

Brands managers shall use focal brands or associated components substantially in every possible channel for information distribution and communication ((Faircloth et al., 2001). Firms extend brands into new product and service categories by using same current brand name or a distinctive with one to enhance competitiveness and reinforce the customer relationship by taking advantage of the digital environment, such as cross-boundary over product categories and physical limitations.

\subsection{E-Branding Strategies}

Business on-line could be viewed as a new-product category because of its distinctive features (Hoffman \& Novak, 1996) that significantly exceed customer's experiences with physical environment (Bergstrom, 2000). Therefore, a line extension strategy may not be appropriate in the on-line environment since customers were lacking similar experience. Characterized with borderless features, brands could easily expose to those market segments that firms never reached. These new markets are those firms may wish to penetrate, but not to enlarge. Therefore, we limit our discussion on two branding approaches in an online context. The first one that extending the current brand on-line is termed as extension-based e-branding approach (e-EBA), and the second to create new brands on-line and is termed as creation-based e-branding approach (e-CBA). Although e-EBA is more preferred than e-CBA (Del Vecchio \& Smith, 2005), advantages and disadvantages were concurrent exist (Aaker, 1990). Disadvantages of e-EBA imply that e-CBA could be a better alternative (e.g. brands with negative image, i.e. brand 'liability').

In general, marketers involve brand and product category to formulate appropriate branding strategies. Managers, whether extending the current brand as brand extension to include product line extension across varied product categories, or instead creating new brands could be seen as a market extension and a new brand strategy (Aaker, 1991). As previous described, we limited our discussion on brand extension and new branding approaches, termed as electronic extension-based approach (e-EBA) and electronic creation-based approach (e-CBA) as the scope of this research. 


\subsection{Extension-Based E-Branding Approach (e-EBA)}

Brand extension's issues have long received a good amount of attention in both academicians and practitioners. Two distinct perspectives on the effects of brand extension emerged in the last decades (Aaker, 1990). One advocates that firms can leverage the quality brands (Park \& Kim, 2001) by penetrating into new-product categories with fewer costs and expenses, larger market share, and greater advertising efficiency (Smith \& Park, 1992). The effectiveness of brand extensions depends on many factors, ranging from customer and supplier factors to uncontrollable external factors and through certain mediating or moderating variables (Czellar, 2003). However, an extension of a current brand with significant equity is useful for brand loyalty to transfer from offline to online (Rafig \& Fulford, 2005), especially for products and services that are fit between parent and e-brand (Czellar, 2003). These effects may even be exaggerated in the cases of high level of product category similarity (Park \& Kim, 2001) or perceived 'fit' (Aaker, 1990). E-brands or web brands appear as extensions of offline brands or simply extensions of communication with current customers (e.g. Barnes \& Noble), as referred as e-EBA. The others argue that higher degree of brand extension tends to have been stronger diluting effects on the parent or original brand names (Keller, 2003), particularly for those extending into a category with low similarity with the parent.

Exploring into the customers' perceptions regarding brand extensions. Although the quality of the brand may benefit its extensions that are perceived "fit" in product categories, elaborations on the attributes of the extensions obtain more satisfactory acceptance than those on the linkages per se of the parent and its extensions (Aaker \& Keller, 1990; Park et al., 2002). Yet, overstated the attributes can also jeopardize extension itself by reducing the attractiveness of extended products. In other words, customer loyalty may not transfer to extension on which firms attempted to leverage the equity of quality brand when deliberately overlooking the link between the original and the extension (Van Osselaer \& Alba, 2003) or bluntly linking unfitted brands (Bridges \& Keller, 2000). To alleviate the negative impacts of brand extension, some recommend managing on product features similarity, brand concept consistency, consistency of benefit claimed (Park et al., 2002), and quality of original brand and its associations (Baoniarczyk \& Alba, 1994). Others suggest well alignment of attributes of extensions, fitness, and physical quality of relationships between the original and the extensions (Bridges \& Keller, 2000). Maintaining brand consistency and continuity while expanding or promoting critical brand components online ensure a better customer preferences and brand values (Faircloth et al., 2001; Stuart \& Jones, 2004), and brand extension approach is nothing but a continuum of the parent brand. Alterative to e-EBA, the e-CBA may represent a preferred policy by not bothering substantial changes that sometimes involve complicated strategic considerations.

\subsection{Creation-Based E-Branding Approach (e-CBA)}

In contrast to brand extension, e-CBA creates a new-brand for a new product category. The disadvantages for brand extension are just the advantages of new brands from which no negative impacts can possibly impose on the others (Aaker, 1991). A newly established brand 
is fully entitled to formulate its own strategy, adopts the most advanced technology, target emerging segments, and free to conduct contingent marketing activities to secure disperse customers. In most cases, possibilities of cannibalization and channel conflicts are low for products with different brands. Effective communications and exposures may foster new brands becoming famous in and being acceptable by certain market segments. In other words, the new brand will have its own brand equity in this particular market. Taking the brand equity as financial assets (Smith \& Parr, 2000), independent brand equity that is separately created can be used to exchange for other resources required by corporate strategy. Splitting is impossible for those brands that were extended from a name shared by member product categories of one family. Possible drawbacks for e-CBA may include greater investments in communication, sales force recruiting and training, difficulty in securing and retaining customers because of lacking the support of brand equity. It is also possible for e-CBA that low possibility of cross selling and knowledge transfer due to no common customer base, and its newness to the market where all other players are new either.

\subsection{The Effect of Brand Equity: e-EBA versus e-CBA}

Brand equity can benefit e-brand by improving the acceptance of such a brand in the Internet (Aaker, 1991). In a virtual environment, pre-purchase examination is impossible, and close observations, and personal trials are not available as customers familiar in traditional transactions. As a result, customers perform extra searches and comparisons before making decisions on any particular products and services, or seek to acquire more extensive promises and guarantees from sellers. This is particularly true for products and services with high involvement of which customers perceive extreme risks. Noteworthy is that such continuing uncertainty and skepticism will significantly magnify suppliers' online operation costs (Durkan et al., 2003). Brand equity helps to reduce the buyers' uncertainty effectively (DelVecchio \& Smith, 2005).

Evidence shows that collaborating with established brands in developing e-brand building approach (Ibeh et al., 2005) benefits on-line branding. With the help brand equity, e-EBA would be easier in receiving customer acceptance and confidence than e-CBA. This infers that extending the accepted brand into on-line setting would obtain better trustworthiness or alleviate distrust and risk perception than those newly created brands (Odom, 2002). However, e-CBA may acquire and secure customer acceptance by innovative utilizing the distinctive Internet features such as product's evaluation / comparison in the virtual environment, particularly when the focal products prices were high, or features were complicated that all need consumer's professional judgment. This would generate the highest extent of value equity in achieving aggregate customer equity (Kotler et al., 1996). We, therefore, conclude the following propositions regarding the dominant drivers for respective e-branding approaches.

Proposition 1: e-EBA will more closely related with brand equity and relationship equity; e-CBA will more closely related with value equity. 


\section{Effects of Tangibilization in Online Business}

\subsection{E-branding and Intangibility of Service}

For firms that follow brand extension policy, branding process may not complete until the targeted brands have also accepted in the virtual contexts. As to the business that attempts to explore opportunities in the cyber marketplaces with new brand policy, proper Internet brand name that is not hinting generic product category would bring business a satisfactory position and return (Ries \& Ries, 2000). Irrespective either branding policies, service intangibility remains the major concerns in service industries (Shostack, 1977; Parasuraman et al., 1988) as well as in virtual environment (Croner, 2000). This denotes that carefully dealing with the intangibility associated effects is essential in making e-branding decisions, since intangibility is a central concern that prevents customers trust instead of functionality of physical features (Shostack, 1977; Croner, 2000). Scholars interpret intangibility as either the impossibility of physically touched or as the difficulty of defines, formulates, or understands clearly and precisely (Berry, 1980). In a more specific way, the concept of intangibility includes the absence of four senses of seeing, smelling, hearing, touching (Flipo, 1988), and touching (Kotler, 2000). Contrast to research concentrating on physical feeling, Rushton \& Carson (1989) termed "mental intangibility" to include those expressions regarding mental feelings other than those physical. This broadens our perspective on intangibility from traditional physical side to mental aspects.

\subsection{Decreasing the Service Intangibility}

The inherent intangibility of the virtual setting brings customers higher perceptions of uncertainty and risk in one hand, i.e. mentally intangible (Stafford, 1996), and supplier's greater worries on how the online service could be properly defined (Berry, 1980; Stafford, 1996) on the other hand. Seeing the difficulty of intangibility in the virtual world, literature on service marketing often encourages suppliers to use tangible cues or develop a robust corporate image to decrease the service intangibility (Santos, 2002). For example, in promoting and leveraging corporate brand, world's top 75 brands registered their brands as domain names to extend brand online both globally and locally to protect their brands (Murphy et al., 2003). Brand registration provides firms reactive legal protection in the virtual context, yet not sufficient in gaining customer acceptance and any forms of customer equity. In order to gain customers' acceptance on e-brands, firms shall perform additional efforts in successful transforming these intangible names into something that could be mentally tangible. Activities adopted to convince customers' tangibility perception is termed as 'tangibilization' (Shostack, 1977; Chen \& Tarn, 1998). Firms that are more willing to gain customers' acceptance will be more aggressive in conducting tangibilization activities. We conclude the discussion as proposition 2 .

Proposition 2: Stronger e-branding efforts will result in higher level of tangibilization. Tangibilization and customer equity 


\section{Effects of Tangibilization in Online Business}

\subsection{Continuum of Service Intangibility}

While there are various definitions on service intangibility, some scholars argue that intangibility and service are not to be defined exactly but to evaluate services according to the degree of intangibility (Zeithaml \& Bitner, 2000), and propose that services vary in terms of degree of perceived intangibility (Miller \& Foust, 2003). This reminds us to examine the service intangibility in a concrete way instead of viewing it as an abstract concept.

Shostack (1977) is among the earliest who discussed this content and created a single dimension to describe the continuum of tangibility/intangibility. The difference between physical goods and service product is the degree of tangible elements included in the respective objects. Later, McDougall \& Snetsinger (1990) developed a relevant instrument for service intangibility measuring. This instrument provides elementary measurement for service in/tangibility, as well as the customers' basic impression toward services. Recently, in response to the necessity of gaining mental tangibility, Santos (2002) suggests to classify service characteristics on a continuum from "tangible dominant" to "intangible dominant" along the continuum of in/tangibility and to provide "tangible evidence". Services in any forms could be found in any points in the continuum between intangible and tangible. Examples for the former could be those exchanges involved with no possession is truly transferred, and those involved physical products with premium prices for its associated services for the latter.

\subsection{Tangibilization by Marketing Activities}

Tangibilization refers to conducting a set of marketing-based activities or using tangible cues or generalizing a corporate image to raise customer's sense of tangibility (Chen \& Tarn, 1998; Santos, 2002). Chen \& Tarn (1998) illustrates four marketing-based activities to tangibilize the service intangibility. This is a four-dimension concept, including Quantitation / ranking, Factual / substantial, Word-of-mouth effect, and Information frequency. Quantitation means the techniques that represent service's contents with quantitative cues; ranking is the relative order in contrast with the competitors or counterparts in terms of service contents. Factual represents those efforts that providers perform to prove service values through a variety of visual messages; substantial is termed to describe the efforts persuading the customers that the service is valuable. Concepts of factual and substantial are similar, yet the former is used to concrete abstract image and invisible resource of service's provider; the latter is to present factual objects. Word-Of-Mouth effect is an influential technique that using the diffusion effects of satisfied customers. Information frequency refers to the amount and density of service's information delivered to customers, including frequency of advertising, activities of sales promotion, number of sales force visiting times, and frequency of provider-client encounters. All these activities or campaigns can be significantly enhanced through unique multi-sensor features offered by advanced web-associated technology.

Therefore, regardless the availability of brand equity, marketing-based tangibilization 
activities would act as important factors in alleviating the customer intangibility perception. The content and extent of tangibilization may vary from one to another due to contingent factors that each branding approach involved.

\subsection{Tangibilization and Customer Equity}

Tangibility is the major predictor for customer satisfaction at the firm level (Wong \& Sohal, 2003). Tangibilization is to materialize the customers' tangibility perception (Ger \& Belk, 1990) and eventually the customer satisfaction and equity.

Technology per se is not the major barrier prevent acceptance of electronic business, but the customer's attitude toward it (Croner, 2000) of which mostly resulting from lacking trust on e-business. Customer's trust and subsequently customer relationships will then be easier to secure and sustain customer preferences (Morgan \& Hunt, 1994). Although a systematic array of associated factors should be included as a whole for trust-building investment (Hong, 2004), study reveals that satisfied needs, responsiveness, reliability in security and technical functions will determine how customers trust online businesses (Gummerus et al., 2003). These factors are all included in so-called 'tangibilization'. In other words, stronger tangibilization conducts will result in a more favorable level of customer equity.

E-brands supported by satisfactory parent brands would have plenty of opportunities in receiving customer loyalty from the parent (Rafig \& Fulford, 2005), so as the perceived tangibility. Although any e-brands can benefited from 'trust-mark' (Durkan et al., 2003), unless the tangibility towards such e-brand is high, transfer of the customer loyalty from the parent brand will be less likely to be effective. Value-based customer relationship is one way to create customer's tangibility perception. Companies can create and maintain a sound customer relationship through a way of delivering valuable services under an identifiable brand or product. The brand serves as value carriers in response to customers' demands. The customer-brand relationship incurred when the targeted customers perceive the values of perceived tangibility. We therefore, conclude the proposition 3:

\section{Proposition 3: Stronger tangibilization will result in stronger customer equity.}

\section{Discussion and Conclusion}

While some scholars limit the tangibility within the scope of tangible contexts, such as the physical facilities (e.g. Parasuraman, et al., 1988), service elements can also bring intangible influences in shaping the participant's perception. This means that customers perceive the existence of these elements and accordingly change their attitudes as a response for their perception on mental tangibility. In virtual environment, similar atmospheres or other tangible element also exist in changing customer's attitudes and behaviors. It is not a strange phenomenon in a virtual world that millions browsers visited popular websites frequently behave like loyal customers to a retail shop. Factors attracting frequent visitors are not those that are physically tangible but mentally tangible. Higher mental tangibility of a brand guarantees superior performance in customer equity with better customer experience and 
lower disconfirmation of customer expectation.

Two main arguments for the notion of brand equity exist, one advocates as financial values that owned by the company (Smith \& Parr, 2000; Aliawadi et al., 2003) and the other suggests viewing it as a product of customer preference and acceptance (Aaker, 1996; Keller, 1993). Since extension-based e-branding heavily drawn its strengths from brand equity, two related questions would be interesting to explore. Does the company that legally possessed the disposition privileges of the brand can truly leverage such an asset at its own will instead of refer to customer acceptance, for example, several extensions to online services? Does the owner of the brand equity shall consult with those who are not the legal owners in its brand exploiting attempts? No matter how effective of the internet efforts in branding, bear in mind is that an e-brand is not actually materialized in nature, its relationship with the consumer's equity or loyalty may be curvilinear rather than linear (Ger \& Belk, 1990).

Effects of e-branding on building and reinforcing customer equity may be contingent due to the differences of perceived risk and uncertainty and perceived intangibility (Keller, 2003). This implies that the interactions of service natures and Internet features may result in unique effects that different from those offline. For example, branding the healthcare services (Gummerus et al., 2003) and financial services (Morrison \& Roberts, 1998) online may be even more difficult to obtain customers trust than in a physical world because the intangibility of the Internet exaggerates the risk and uncertain perception.

It is important to note as well that the ways of e-brands attempted to communicate with targeted segments may not be the same as those in off-line regardless branding strategies. While the extension grounded on the off-line brand, whether the positioning of such extension shall be hold consistent with the current would be interesting to explore. New brand strategies may not expose to the alignment with any brand. It needs to consider the alignment between on-line and off-line when the brand is launched simultaneously. Since customers varied in terms of communication patterns (Heinonen \& Strandvik, 2005), how the communication pattern works between on-line branding and varied groups of customers may predict the success and failure of gaining customer equity of a brand.

We have discussed other possible sources of effect that may affect the relationship between e-branding and customer equity, and suggest conducting empirical tests on the mediating effects of tangibilization in various contexts. Timing factors would be important to consider when launching an E-brand as well. Issues of this kind may include such as on what stage of the life cycle, on what level of brand acceptance offline before going online for e-EBA? Other factors regarding the timing problem may include the institutional infrastructure (e.g. legal, industrial standards and practices, economic and others that regulated the electronic transaction), infrastructure of electronic setting, stages of readiness of targeted customers, status of competition, possible effects that might ignite fierce competition (e.g. price wars). Since quality brands with acceptable brand equity (i.e. level of customer acceptance) is essential for extension-based e-branding, firms may first foster focal brand offline in targeted market segments. Launching a new brand always represent a major investment in 
communicating with the markets. Costs of investment might be double while concurrent launching the parent online and the extension offline or vice versa, because neither brands were known and accepted by the targeted markets. There are also needed for clarifying the possible overlaps between brand equity and tangibilization, and the cause effects of tangibilization on brand equity.

\subsection{Conclusion and Practical Implications}

The internet technology had forced a boundary spanning of a firm, and draw the firm's operational focus away from the real to a virtual environment (Walsh \& Godfrey, 2000). In the other hand, online environment was also new and suspicious that exceeded current customers' ideology and experiences while on exchange. For both parties in an exchange, an online service or business was a synonym of a new category of product.

The importance of customer equity in business operation is never overemphasized. Composed by brand equity, value equity, and relationship equity, customer equity is obviously a major challenge to marketers in e-business where is characterized with extreme intangibility. We thus propose a conceptual framework illustrating the relationship between e-branding, tangibilization, and customer equity. The availability and use of brand equity differentiate brand-extension and new brand approach from which infers that the activities an e-EBA approach took to build customer equity will be quite different from those follow e-CBA. The goal in building customer relationship with higher-value segments, i.e. relationship equity, is the same regardless the methods applied and the branding strategies adopted.

Brand equity is an asset as long as customers accept it. When brand equity is available, brand can be an exploitable equity in extending to different product category (DelVecchio \& Smith, 2005). For brand that not supported by brand equity, new brand approach is the favorable alternative by taking the advantages of free from connection with previous commitment or liability (Aaker, 1991). Although extant research reveals the practices of firms' successfully transferring customer loyalty from offline to on-line (Rafig \& Fulford, 2005), numerous cases indicated that new brand approach also brought brilliant success in the on-line contexts. For example, Barnes and Noble took 2.0 years to reach $\$ 100$ million sales online by successfully transferring customer loyalty from the physical bookstore, compare to 2.9 years for Amazon. However, Amazon, a new brand to customers, becomes the biggest book retailer in on-line shopping (Ries \& Ries, 2000). While numerous literatures focus on the on-line branding activities, there is none or few if any explored the issues regarding the differences and associated outcomes between e-EBA and e-CBA. Without support of brand equity, new brand can be more flexible in fully embracing updated technology to customize its services to individual customers in the online setting. Instead of pursuing brand equity, e-CBA may strive for the value equity and possible future relationship equity. We propose that both EBA and CBA are able to gain success in the cyber marketplaces. In practice, avoiding compete in 'red sea' but pursuing business goals in 'blue ocean' would be better strategic alternative for new firms in the virtual market. 
The extreme intangibility as inherent nature of virtual environment suggests the necessity of tangibilization for e-branding. We conclude that tangibilization will mediate the relationship between e-branding and customer equity. Due to the mediating effects of tangibilization, e-branding that is heavier tangibilized regardless the availability of an offline brand is superior to the others in terms of creating and retaining quality customer equity. Tangibilize activities would be varied from one context to another depends on the particular needs of focal customers. Managers shall first identify the key criteria in market segmentation, and accordingly foster such segment with comprehensive services to tangibilize their brands in such customers' perception.

Building online would further increase customer's perceived value from which not only help to strengthen the relationship with customers by signaling 'we care' to customers, but also creates a marketplace for new customers who are not appropriately served through traditional channels. Successful offline brands could be leveraged to online contexts. Satisfactory performance obtained online could be reciprocally transferred offline. The key determinant for the success of either transfer is the effectiveness and efficiency of tangibilization. This implies that managers shall establish electronic business as an extension of current business to integrate overall services or as a new business to serve those customers who are remote located and prevented by national or geographical barriers. To be successfully secure treasures (customer equity) in 'blue ocean' sailing (online markets adventures), sails (brand) per se is essential but not sufficient. Arming the ship with dependable machine or power, supplies, operating system, and sailing techniques (tangibilization activities) that materially signaling trustworthiness to the targets and passengers are all needed for the journey.

\section{Acknowledgement}

Partial content of this manuscript was presented in the Academy of International Business South-East Asia Regional (AIB-SEAR) Conference in 2007 at Macau, China, and in the Pan-Pacific Management Forum (PPMF) in Kaohsiung, Taiwan. The authors thank for the valuable contributions made by Dr. Paul Chang, and Ms. Kim Chen (a PhD. Candidate) in the conference, their comments and opinions and literature input are essential elements of this manuscript.

\section{References}

Aaker, D. A. (1990). Brand extensions: The good, the bad, and the ugly. Sloan Management Review, 31(4), 47-56.

Aaker, D. A. (1991) Managing brand equity, The Free Press: New York.

Aaker, D. A. (1996).Measuring brand equity across products and markets. California Management Review, 38, 102-120. http://dx.doi.org/ 10.1108/03090561211230124

Aaker, D. A., \& Keller, K. L. (1990). Consumer evaluations of brand extensions. Journal of Marketing, 54, 27-41. http://dx.doi.org/ 10.2307/1252171 
Aliawadi, K. L., Lehmann, D. R., \& Neslin, S. A. (2003). Revenue premium as an outcome measure of brand equity. Journal of Marketing, 67(4), 1-17. http://dx.doi.org/ 10.1509/jmkg.67.4.1.18688

Balachander, S., \& Ghose, S. (2003). Reciprocal spillover effects: A strategic benefit of brand extensions. Journal of Marketing, 67(1), 4-13. http://dx.doi.org/ 10.1509/jmkg.67.1.4.18594

Baoniarczyk, S. M., \& Alba, J. (1994). The importance of the brand in brand extension. Journal of Marketing Research, 31, 214-228. http://dx.doi.org/ 10.2307/3152195

Baron, R. M., \& Kenny, D.A. (1986). The moderator-mediator variable distinction in social psychological research: Conceptual, strategic, and statistical considerations. Journal of Personality and Social Psychology, 51, 1173-1182. http://dx.doi.org/ 10.1037/0022-3514.51.6.1173

Bergstrom, A. (2000). Cyberbranding: Leveraging your brand on the Internet. Strategy \& Leadership, 28(4), 10-19. http://dx.doi.org/ 10.1108/10878570010378645

Berry, L. L. (1980). Services marketing is different. In C. H. Lovelock, Services marketing, 29-37. Englewoods Cliffs, New Jersey: Prentice-Hall.

Blattberg, R. C., \& Deighton, J. (1996). Manage marketing by the customer equity test. Harvard Business Review, 74,136-144. http://dx.doi.org/ 9607100440

Bolton, R. and Drew, J. (1991). A longitudinal analysis of the impact of service changes o customer attitudes. Journal of Marketing, 55, 1-9. http://dx.doi.org/10.2307/1252199

Bottomley, P. A., \& Holden, S. J. S. (2001). Do we really know how consumers evaluate brand extensions? Empirical generalizations based on secondary analysis of eight studies. Journal of Marketing Research, 38, 494-500. http://dx.doi.org/10.1509/jmkr.38.4.494.18901

Bridges, S., \& Keller, K. L. (2000). Communication strategies for brand extensions: Enhancing perceived fit by establishing explanatory links. Journal of Advertising, 29(4), 1-11. http://dx.doi.org/ 10.1080/00913367.2000.10673620

Cespedes, F. V. (1996). Beyond teamwork: How the wise can synchronize. Marketing Management, 5, 24-37. http://dx.doi.org/11254708

Chen, C. N. \& Tarn, D. C. (1998). Marketing-based tangibilization for services: Model construction and experimental investigation. Management Review, 17, 27-60. (In Chinese)

Croner, C. C. H. (2000), Croner's Electronic Commerce. Burgess Hill: Selwood.

Czellar, S. (2003). Consumer attitude toward brand extensions: An integrative model and research propositions. International Journal of Research in Marketing, 20, 97-115. http://dx.doi.org/ 10.1016/S0167-8116(02)00124-6

De Chernatony, L. (2001). Succeeding with brands on the Internet. The Journal of Brand Management, 8(3), 186-195. http://dx.doi.org/ 10.1057/palgrave.bm.2540019 
DelVecchio, D., \& Smith, D. C. (2005). Brand-extension price premiums: The effects of perceived fit and extension product category risk. Journal of Academy of Marketing Science, 33, 184-196. http://dx.doi.org/ 10.1177/0092070304269753

Durkan, P., Durkin, M., \& Gillen, J. (2003). Exploring effects to engender on-line trust. International Journal of Entrepreneurial Behavior\& Research, 9, 93-110. http://dx.doi.org/ $10.1108 / 13552550310476184$

Dussart, C. (2001). Transformative power of e-business over consumer brands. European Management Journal, 19, 629-637. http://dx.doi.org/ 10.1016/S0263-2373(01)00088-3

Faircloth, J. B., Capella, L. M., \& Alford, B. L. (2001). The effect of brand attitude and brand image on brand equity. Journal of Marketing Theory and Practice, 9, 61-74. http://dx.doi.org/ 5743042

Flipo, J. P. (1988). On the intangibility of services. The Service Industries Journal, 8, 286-298. http://dx.doi.org/10.1080/02642068800000044

Ger, G., \& Belk, R. W. (1990). Measuring and comparing materialism cross-culturally. In M. E. Goldberg, G. Gorn, \& R. W. Pollay. Advances in Consumer Research Volume 17, eds. Provo, UT: Association for Consumer Research, 186-192.

Gummerus, J., Liljander, V., Pura, M., \& van Riel, A. (2003). Customer loyalty to content-based Web sites: The case of an online health-care service. Journal of Services Marketing, 18, 175-186. http://dx.doi.org/ 10.1108/08876040410536486

Gupta, S., Lehmann, D. R., \& Stuart, J. A. (2004). Valuing customers. Journal of Marketing Research, 41, 7-18. http://dx.doi.org/ http://dx.doi.org/10.1509/jmkr.41.1.7.25084

Heinonen, K., \& Strandvik, T. (2005). Communication as an element of service value. International Journal of Service Industry Management, 16, 186-198. http://dx.doi.org/10.1108/09564230510592306

Hoffman, D. L., \& Novak, T. P. (1996). Marketing in hypermedia computer-mediated environments conceptual foundations. Journal of Marketing, 60, 50-68. http://dx.doi.org/ $10.2307 / 1251841$

Hong, Y. (2004). Factors influencing consumer perceptions of brand trust online. Journal of Product \& Brand Management, 13, 329-342. http://dx.doi.org/10.1108/10610420410554412

Horsky, D., Nelson, P., \& Posavac, S. S. (2004). Stating preference for the etheral but choosing the concrete: How the tangibility of attributes affects attribute weighting in value elicitation and choice. Journal of Consumer Psychology, 14, 132-140. http://dx.doi.org/ 10.1207/s15327663jcp1401\&2_15

Ibeh, K. I. N., Luo, Y., Dinnie, K., \& Han, M. (2005). E-branding strategies of internet companies: Some preliminary insights from the UK. Journal of Brand Management, 12, 355-373. http://dx.doi.org/10.1057/palgrave.bm.2540231 
Ilfeld, J. S., \& Winer, R. S. (2002). Generating Website traffic. Journal of Advertising Research, 42(5), 49-61.

Indrajit, S. (2001). Cost transparency: The net's real threat to price and brands. Harvard Business Review, 78, 43-50. http://dx.doi.org/ 2839589

Keller, K. L., \& Sood, S. (2003). Brand equity dilution. Sloan Management Review, 45(1), $1-12$.

Keller, K. L. (1993). Conceptualizing, measuring, and managing customer-based brand equity. Journal of Marketing, 57, 1-22. http://dx.doi.org/ 10.2307/1252054

Keller, K. L. (2002) Strategic brand management (2nd Ed.). New Jersey: Prentice Hall.

Kotler, P. (2000) Marketing management, Prentice-Hall International: New Jersey.

Kotler, P., Ang, S. H., Leong, S. M., \& Tan, C. T. (1996). Marketing Management-an Asia Perspective (3rd Ed.). Singapore: Pearson.

Li, H., Daugherty, T., \& Biocca, F. (2002). Impact of 3-D advertising on product knowledge, brand attitude, and purchase intention: The mediating role of presence. Journal of Advertising, 31, 43-57. http://dx.doi.org/10.1080/00913367.2002.10673675

McDougall, G. H. G., \& Snetsinger, D. W. (1990). The intangibility of services: Measurement and competitive perspectives. The Journal of Services Marketing, 4, 27-40. http://dx.doi.org/10.1108/EUM0000000002523

Miller, D. W., \& Foust, J. E. (2003). Classifying services by tangibility/intangibility of attributes and benefits. Services Marketing Quarterly, 24, 35-55. Http://dx.doi.org/10.1300/J396v24n04_03

Morgan, N. A., \& Hunt, S. (1994). The commitment-trust theory of relationship marketing. Journal of Marketing, 58, 20-38. http://dx.doi.org/ 10.2307/1252308.

Morris, J. D., Woo, C. M., \& Cho, C. H. (2003). Internet measures of advertising effects: A global issue. Journal of Current Issues \& Research in Advertising, 25, 25-53. http://dx.doi.org/10.1080/10641734.2003.10505139

Morrison, P. D., \& Roberts, J. H. (1998). Matching electronic distribution channels to product characteristics: The role of congruence in consideration set formation. Journal of Business Research, 41, 223-229. http://dx.doi.org/ 10.1016/S0148-2963(97)00065-9

Odom, M. D. (2002). Web assurance seals: How and why they influence consumer's decisions. Journal of Information Systems, 16, 231-250. http://dx.doi.org/ $\mathrm{abs} / 10.2308 / \mathrm{jis} .2002 .16 .2 .231$

Oliver, R. L. (1997). Satisfaction: A behavioral perspective on the consumer. Boston, MA: McGraw-Hill. 
Page C., \& Lepkowska-White, E. (2002). Web equity: a framework for building consumer value in online companies. Journal of Consumer Marketing, 19, 231-248. http://dx.doi.org/ $10.1108 / 07363760210426058$

Parasuraman, A., Zeithaml, V., \& Berry, L. L. (1988). SERVQUAL: A multiple-item scale for measuring customer perceptions of service quality. Journal of Retailing, 64(1), 12-40.

Park, C. W., \& Kim, K. H. (2001). Role of consumer relationships with a brand in brand extensions: Some exploratory findings. Advances in Consumer Research, 28(1), 179-185.

Park, C. W., Kim, K. H., \& Kim, J. K. (2002). Acceptance of brand extensions: Interactive influences of product category similarity, typicality of claimed benefits, and brand relationship quality. Advances in Consumer Research, 29, 190-198.

Rafig, M., \& Fulford, H. (2005). Loyalty transfer from offline to online in the UK grocery industry. International Journal of Retail \& Distribution Management, 33, 444-460. http://dx.doi.org/ 10.1108/09590550510600861

Reichheld, F. F. (1996). The loyalty effect: The hidden force behind growth, profit, and lasting value. Cambridge, Massachusetts: Harvard Business School Press

Reinartz, W., \& Kumer, V. (2000). On the probability of long life-time customers in a noncontractual setting: An empirical investigation and implications for marketing. Journal of Marketing, 64, 17-35. http://dx.doi.org/ abs/10.1509/jmkg.64.4.17.18077

Ries, A., \& Ries, L. (2000). The 11 immutable laws of internet branding. NY: Harper Information.

Rushton, A., \& Carson, D. J. (1989). The marketing of services: Managing the intangibles. European Journal of Marketing, 23, 23-44. Http://dx.doi.org/ 10.1108/EUM0000000000582

Rust, R. T., Lemon, K. N., \& Zeithaml, V. A. (2004). Return of marketing: using customer equity to focus marketing strategy. Journal of Marketing, 68, 109-127. http://dx.doi.org/ 10.1509/jmkg.68.1.109.24030

Santos, J. (2002). From intangibility to tangibility on service quality perceptions: A comparison study between consumers and service providers in four service industries. Managing Service Quality, 12, 292-302. http://dx.doi.org/ 10.1108/09604520210442083

Schultz, D. E. (2003). Branding geometry. Marketing Management, 12, 8-9.

Shostack, G. L. (1977). Breaking free from product marketing. Journal of Marketing, 41(2), 73-80. http://dx.doi.org/ 10.2307/1250637

Smith, M. D., \& Brynjolfsson, E. (2001). Consumer decision-making at an internet shopbot: Brand still matters. The Journal of Industrial Economics, 49(4), 541-558. http://dx.doi.org/ 10.1111/1467-6451.00162

Stafford, M. R. (1996). Tangibility in services advertising: An investigation of verbal versus 
visual cues. Journal 2014, Vol. 5, No. 1

http://dx.doi.org/10.1080/00913367.1996.10673504

Stuart, H., \& Jones, C. (2004). Corporate branding in marketplace. Corporate Reputation Review, 7(1), 84-93. http://dx.doi.org/10.1057/palgrave.crr.1540213

Trivedi, M., \& Morgan, S. (2003). Promotional evaluation and response among variety seeking segments. Journal of Brand product \& Brand Management, 12(6), 408-425. http://dx.doi.org/ 10.1108/10610420310498830

Van Osselaer, S. M. J., \& Alba, J. W. (2003). Locus of equity and brand extension. Journal of Consumer Research, 29(4), 539-550. http://dx.doi.org/ 10.1086/346249

Walsh, J., \& Godfrey, S. (2000). The Internet: A new era in customer service. European Management Journal, 18(1), 85-92. http://dx.doi.org/ 10.1016/S0263-2373(99)00071-7

Wong, A., \& Sohal, A. (2003). Service quality and customer loyalty perspectives on two levels of retail relationship. Journal of Services Marketing, 17(5), 495-413. http://dx.doi.org/ 10.1108/08876040310486285.

Zeithaml, V. A., \& Bitner, M. J. (2000). Services marketing: Integrating customer focus across the firm. New York: McGraw-Hill.

\section{Copyright Disclaimer}

Copyright for this article is retained by the author(s), with first publication rights granted to the journal.

This is an open-access article distributed under the terms and conditions of the Creative Commons Attribution license (http://creativecommons.org/licenses/by/3.0/). 